\title{
Teacher educators' perspectives on shaping a preschool teacher education while dealing with internal and external demands
}

\author{
Katarina Ribaeus and Annica Löfdahl Hultman
}

\begin{abstract}
Being a teacher educator (TE) of today is often described as a complex task. TEs have to deal with internal demands from students, colleagues and leaders and with external demands from state authorities when shaping the education programme in which they teach. The present article focuses on TEs in Swedish preschool teacher education and aims to explore how commitment to and demands, inside and outside the higher education system, are handled and reflected upon, specifically the demands on considering student-centred learning. Results from interviews with 10 TEs show a perceived lack of support from the faculty board and its office and how colleagues contribute to tensions but also are perceived as supportive colleagues to learn from. Results also show the TEs' efforts to overcome less desirable traditions. The combined results show how TEs are part of webs of commitments regarded as related fields and threads dependent on each other rather than separate parts, making the web/teacher education programme fragile. If any part breaks, the whole programme will be damaged. The discussion relates to how to overcome traditions and making actors in the programme shape a future-directed good education together.
\end{abstract}

Keywords: public good; student-centred learning and teaching; teacher agency; teacher education; webs of commitments

\footnotetext{
Received 4 May 2021; revised version received 17 January 2022; accepted 21 January 2022. Corresponding author: Katarina Ribaeus, Karlstad University, Sweden(katarina.ribaeus@kau.se).
}

\section{Introduction}

This article explores teacher educators' perspectives on experiences, demands and commitments and how these aspects affect the shaping of the preschool teacher education for both teacher educators and students. Teacher education has for many years been, and still is, blamed for school failure of many kinds (Lilja, 2010; SoutoManning, 2019). Public debate and critique of teacher education in general holds more demands and challenges than strengths, as shown by Edling and Liljestrand 
(2020). They categorised the challenges found in the current Swedish media debate into four themes: 'woolly scientific basis, insufficient knowledge, shortage of teachers and disciplinary problems' (p. 258). Edling and Liljestrand interpret the themes as based on external experts who should guide teachers' actions towards an 'outside-in-professionalism' (p. 256). Another outside perspective on the teacher education is the recurrent evaluations made by the Swedish higher education authority (UKÄ). One of UKÄs' missions is to monitor compliance with laws and regulations among universities and university colleges when evaluating the quality of higher education. As shown for example by Sjöberg (2019), Swedish teacher education is 'the higher education programme that is most regulated and evaluated by the Swedish government' (p. 37). Besides, for teacher educators there are internal demands to take into account, such as the faculty leaders, colleagues and not the least, the students in what Solbrekke et al. (2020) refer to as webs of commitments. In our interpretation, the TEs webs of commitments hold different but related, often overlapped and competing fields in which demands from both inside and outside have to be dealt with.

This study is part of a project in which we simultaneously, but separately, study both student teachers' perspectives (Löfdahl Hultman \& Ribaeus, 2021, Ribaeus, Enochsson, \& Löfdahl Hultman, 2020) and teacher educators' perspectives within the same preschool teacher education programme, at a mid-size Swedish higher education institution (HEI). In this article, the data consist of interviews with 10 experienced teacher educators. At the time of the study, the preschool teacher education programme was subjected to a national evaluation by UKÄ, which resulted in requested programme changes to ensure quality. The local preschool teacher education was under a one-year review to address the deficiencies and submit an action report to UKÄ. One aspect evaluated by UKÄ was to what extent students' perspectives are taken into account. All national preschool teacher education programmes were successful in that respect. Nevertheless, some of our results from the study on students' perspectives revealed issues of their perspectives being partly neglected (Löfdahl Hultman \& Ribaeus, 2021). During the interviews, we presented such results from the other related study to the TEs. We might expect the TEs in our study to be affected by the results of this study, but also from the public debate, the government regulations and the ongoing UKÄ review process.

In this article, our approach is to highlight the teacher educators' own perspectives (in contrast to external experts' perspectives) on the teacher education programme in which they teach. The aim is to explore how commitment to and demands from different actors, inside and outside the higher education system, are handled and reflected upon by the teacher educators, specifically the demands on shaping a student-centred learning approach. The research questions guiding our analyses are: 
1. With what support and with what tools do teacher educators plan and realise the overall preschool teacher education programme?

2. In what ways do teacher educators interpret and understand external and internal demands related to their teaching assignment?

3. How do teacher educators take into account students' perspectives and conditions when shaping a student-centred learning approach?

\section{Being a teacher educator in higher education of today}

There is a minimum of attention to what teacher educators should know and be able to do, according to Goodwin et al. (2014). Their results from a survey on the topic show that teacher educators feel it is challenging to navigate between policies of programs, departments, colleges/universities, and local/state/national government agencies. Moreover, they noted how 'often the agendas and policies of these stakeholders conflict with one's own commitments to teacher education' (Goodwin et al., 2014, p. 293). Similarly, being a teacher in higher education of today is often described as a complex task and as being one of several parts within webs of commitments (Solbrekke et al., 2020). It means teachers have to deal with demands from controlling state authorities as well as local faculty boards, the expressed professional standards, goals to reach, colleagues, institutional norms and values and, not the least, the students.

Hoidn and Klemenčič (2021) characterize higher education of today as a student-centred ecosystem. Students' perspectives are often theorised as the concept of student-centred learning and teaching (SCLT). It has been long known in higher education research (cf. Trigwell, Prosser, \& Waterhouse, 1999) that relationships between university teachers and students are important for a good learning environment and for students to develop their knowledge. Research in this area emphasizes constructive relationships and an environment that affirms the student (Toom et al., 2017). As it has been an issue for several years to shape nonhierarchical interplay between academic, practitioner, and community expertise (Zeichner, 2010), we might, when webs of commitments relate to teacher educators, add the relation to practice and the local teacher educators at the students' practicum places. These webs of commitments also work as support and are necessary. Nevertheless, they are causing teacher educators challenges, worries and feelings of being controlled.

SCLT is often placed within progressive ideas of education (Fitch, 2017) and described as education that invites students to take an active role in the learning process, i.e., that the education is designed based on student-centred learning. 
However, as stated by Hoidn and Klemenčič, (2021), the concept remains somewhat poorly defined, under-researched and often misinterpreted. Although several handbooks exist on how to succeed with a student-centred learning approach. There is no quick and easy way to teach in more student-centred ways (Green \& Harrington, 2020). McKenna and Quinn (2021) list some misconceptions and misapplications to be aware of, as the SCLT approach 'contradicts the structural and cultural conditions in the context in which it is implemented' (p. 118). Even though teacher educators as well as course validation documents (including the main course documents at the HEI we study) and evaluation reports repeat the notion of SCLT, it may, as argued by Greener (2015), appear as it is a required criterion for academic credibility rather than a well-defined concept.

Such academic credibility and the demands to perform and visualise one's goals, means and results is similar to what Ball (2006) described as being in a performative and standards-based education system. In policy research, standardized models presented via supranational institutions in recent decades as a promotion of effective teaching practice (OECD, 2005, 2009) are often criticized and considered a threat to teachers' opportunities to develop responsible professionalism (Solbrekke \& Englund, 2011). In addition, they create a professionalism that is limited by contextual factors and a standardized curriculum (cf, Oolbekkink-Marchand et al., 2017). Murray (2012) argues that 'the increase in performativity cultures is a global phenomenon which has impacted in some way on all who work in teacher education, wherever their university is located and whatever the national context' (p. 19). Although teacher educators, as Murray also suggests, often adapt their teaching to be more debate-oriented and related to pedagogical dilemmas. However, such teaching is considered too time-consuming and difficult to measure and report. This is why it often remains invisible. Similarly, we may consider it too time-consuming for teacher educators to engage in the possibility of developing a well-defined SCLT.

\section{Theoretical grounds and analytical concepts}

In this article, we strive to situate teacher education and teacher educators' perspectives in a future-directed idea about education as public good. To paraphrase Goodwin et al. (2014), it is an education 'not only for their own (preservice) students but also for the learners whom those students will teach' (p. 293). Public good, in the meaning of the benefit of all, is contrasted to private good, which means

exclusive and of personal benefit. According to a very recent publication, gathering a number of scholars reflecting on leading higher education as and for public good, the notion cannot be taken for granted (Solbrekke \& Sugrue, 2020). In sometimes 
conflicting webs of commitment, public good is challenged, must be negotiated and compromises have to be dealt with. We are inspired by Solbrekke and Sugrue (2020) to search for what might be fruitful concepts when understanding preschool teacher education as and for public good, from the teacher educators' perspective. Sugrue and Solbrekke (2020) argue that higher education is about norms and values to be upheld and promoted in public spheres. They use the metaphor of children's playground to show how those who set the rules also get a better chance to win the games; ' ...the workplace conditions created in higher education public institutions are the "playgrounds" of both staff and students. The space has rules and norms about teaching, learning, research and assessment, overlaid with codes of professional conduct and ethical behaviour ...' (p. 18). Furthermore, the authors argue there is a fluidity of norms and policy shifts, bringing consequences for working conditions in higher education that call for both 'courage and capacity to be proactive' (p. 19) in the mandate to provide education as and for public good. In elaborating the concepts of public and private good in HEI, Englund and Bergh (2020) ask 'what means do they have to encourage the public good and in what ways and with what tools do academics who lead different activities consider their choices?' (p. 37). Moreover, Englund and Bergh argue the need to make use of dialogue and deliberation to cultivate and promote public good. Such actions might strengthen the shared moral consciousness and reduce the influence of ideas about private good. The key concepts we use from the idea of webs of commitments when sorting and analysing our data are; overlaps, challenges, negotiations, compromises and mismatches. We have also analysed what these teacher educators' webs of commitments hold in terms of support, demands and tools.

When it comes to understanding the teacher educators' reasoning about their teaching actions, we rely on the theory on Teacher Agency (Biesta, Priestly, \& Robinson, 2015; Priestley, Biesta, \& Robinson, 2015). The main idea in the theory is that teachers' agency, their capability to act in the present and to express ideas and visions for the future builds on their experiences, making experiences a key concept in our analyses. Teachers' possibilities to act relate to the surrounding context and what Priestley et al. (2015) describe as an ecological system holding cultural, structural and material aspects, in which we situate the teacher educators' actions. Thereby the cultural, structural and material aspect are additional key concepts in our analyses. In our data, cultural aspects mean collective notions about a good preschool teacher education, structural aspects deal with the social support teacher educators get from their faculty boards and colleagues etc. Material aspects can be both working conditions in the HEI and what groups of students attending the preschool teacher education. The contextual aspects relate to the fields in the webs of commitments, thereby making our theoretical grounds overlapping. We might say that teacher educators' possibilities to act depend on how the webs of 
commitments are shaped. Following this reasoning, our second analytical concept comes from teacher agency and includes ideas of what experiences teacher educators bring when formulating their visions of teaching actions within their webs of commitments. When analysing the teacher educators' perspectives on conditions for pursuing a good education, we also search for signs of content and forms shaping a student-centred education as well as what might be interpreted as visions of an education as and for public good.

\section{Materials, methods and analysis}

The data for this study consist of interviews with 10 teacher educators (TE), men and women from a Swedish HEI. These TEs were chosen as they represent all seven semesters, which are included in the current Swedish preschool teacher education. They had a range of different teaching experience and subject tradition. All of them were working at campus in regular courses in the preschool teacher education. Among them, we find subject TEs and TEs directed towards preschool didactics as well as educational theorists. Initially, we asked 13 TEs to participate but three refrained from participating. All participants gave their informed consent. Both authors conducted interviews between autumn 2019 and spring 2020.

The interviews were semi-structured (Bryman, 2011) and focused on issues about being a TE in the preschool teacher education programme. Our interview guide included issues about previous teaching experiences, about demands and commitments in their current situation as well as their visions about a future preschool teacher education programme. We regard the interview situation as an inter-action in which we as researchers and TEs jointly constructed knowledge during the interviews (Brinkmann \& Kvale, 2014). After a short warm-up-talk on their teaching experiences, we introduced our results from a related study on student teachers' perspectives in the same HEI, who felt pressure, perceived that there was too much content in the courses and felt their perspectives being partly neglected (Löfdahl Hultman \& Ribaeus, 2021). This introduction served as a trigger to get the TEs views about demands and commitments in their current work. During the interviews, we were sometimes part of a discussion and sometimes we asked questions to get their views on, for example, general student demands and quality issues in the programme. Due to this methodological inter-action approach, we might say we were sharing the views the TEs talked about. However, when reflecting on the interviews afterwards, we noticed some parts that made us surprised. One example is when one TE told us about the impossibilities to change the syllabi to make it fit current base of knowledge in the field of subject. What also surprised us was the missing or lacking support from the faculty board and its office. 
We do not know if our reactions on these parts have had any effect on the continuing interview and possible interpretations. It should be pointed out that any interview is always heavily affected by those involved, and this study is not an exception. As mentioned initially, the time for data collection coincided with the time when the TEs were addressing the deficiencies on quality and submitted an action report to UKÄ. It is reasonable to assume that it has affected their experiences.

Each interview took place at the local HEI in which the TEs work and lasted for about 1 hour. We recorded nine interviews and wrote down notes on one of them. In the first analytical step, the notes were transcribed and recordings from each interview were listened to before being partly transcribed verbatim, and partly summarised as a text document. The summarised parts include facts and content about the preschool teacher education already familiar to us, such as the length of the programme and the national organisation. Verbatim transcribed parts (approx. 15,000 words) capture the TEs stories about their work, experiences and visions. These parts of the data were then further analysed by using content analysis (Bryman, 2011). According to Bryman, content analysis means structuring the data according to predefined categories, which means data were coded as part of a webs of commitments when we search for cultural, material and social aspects that shaped these webs. During the analysis, we also searched for experiences and descriptions of how the TEs work and what visions they expressed. From these results, we have searched for statements that show aspects of student-centred learning and ideas of education as and for public good.

\section{Results: Teacher educators' webs of commitment}

The results relate to our theoretical grounds, where these TEs' webs of commitments are presented as closely related to and dependent on each other. The most frequent commitment relates unsurprisingly to the students and answer the third research question. Furthermore, the first and second research questions are answered through the TEs dealing with other commitments in the webs that are colleagues, content and structures, leaders and steering as well as norms, values and traditions. Research questions are referred to in the result section by adding the corresponding RQ in parentheses. All these commitments are, in different ways, affecting the possibilities to shape the preschool teacher education programme, especially in a student-centred direction and in a future direction as and for public good.

During the interviews, we were told about situations when compromises had to be done and when the TEs were not happy with their efforts. Nevertheless, our overall impression from the interviews was that the TEs do their very best to 
contribute to a good preschool teacher education. Quotes from the interviews are translated from Swedish into English; thereby some nuances may have been lost, though we have tried to capture the essence of the TEs' voices. We have chosen to remove identifying parts such as gender, subject-specific statements and the semester in which they work.

\section{Students of today: changing commitments}

Several TEs talked about changing commitments due to changes in the current student groups' capabilities and conditions. One concern was how todays' students need more study support. What seemed to engage, and even upset, the TEs were the students' search to find 'the right answer'. One educator expressed it as follows:

Today's students are more mixed and heterogeneous than before. There is a greater difference in their writing abilities, for example, and how they perform their knowledge and how they discuss. They seem to believe there is a right and a wrong way to perform, they do not seem to have realised the degree of freedom when submitting a written task, which leads to a lesser degree of reflexion related to their coming profession.

The TEs described the student group as more stressed and unsecure than before, becoming completely broken if they fail a task. At the same time, the students were reported to be more critical than before, which some TEs regarded as something positive.

Yet, some other TEs stressed the difficulties to teach what they referred to as 'weak students'. It might mean students with learning disabilities, for example dyslexia, or suffering from insufficient prior knowledge. In the subject courses, students need to be present during classes and to take advantage of the additional support provided, for example meeting up with the TEs to ask questions before an exam. However, many of them did not take the opportunities that were offered. One TE talked about how to support the students:

It is a huge assignment to educate and support the students' educational journey. I think those who are not good enough should not be here. We have to find a middle way. Students must be receptive and take responsibility for their own knowledge, their own journey.

One great issue discussed by several TEs was the students' private commitments having a negative impact on their studies. For example, the students had family commitments, had to commute long distances, or had a part-time or a full-time job as a preschool teacher Moreover, students did not always find lecturers were up to 
date, but instead were teaching content that was no longer valid or useful in current preschools. As expressed by one TE, who claimed that not everything could be the most up-to-date knowledge: 'Old stuff can sometimes be important to know as a background and students need to be aware of that up-to-date knowledge has been developed from this ground.'

Another TE looked at the students' experiences from preschool in a positive manner, although they also considered it a problem when studies become less important:

Those who have already started to work may also find it difficult to grasp the importance of how much they really learn in the teacher education programme. They quickly establish ideas about how it should be. What I can do is to problematize the profession or knowledge in relation to it. The practical experience from working life can sometimes conflict with what we want to convey. In an exciting way, so you can take advantage of it. See it as opportunities for dialogue.

These examples, as we argue, show the TEs' changing commitment vis-à-vis the students (RQ3). This part of the web relates to both cultural and material aspects in the ecological system, including notions about a good preschool teacher education and the group of students attending. When demands on more supportive teaching coincide with absent students and requests to be more up to date, we can imagine increased demands on communication and collaboration between colleagues within the preschool teacher education programme.

\section{Colleagues: commitments of support and tensions}

Besides the students, one part of the webs of commitments deals with the colleagues (RQ1). In a programme that goes on for seven semesters, including many different subjects, the TEs meet with many colleagues. Colleagues can be both an obstacle and an opportunity. One TE says:

We are so many teachers, which is a problem. We also represent the content, but as we are many, we need to create a common approach, for example working with real cases. However, it does not happen due to lack of knowledge or lack of time. Such things can arouse anger among the students.

The same TE also expressed the need of having colleagues from whom to ask for support when preparing a task or examination as a help to proceed. 
The TEs are organised in a teacher council, in which they discuss common and general issues in the programme. The council serves as an arena to share knowledge on aspects focused on each semester. Nevertheless, as one TE described, the council meetings are an arena within which TEs can whine at each other: 'It is like when someone comes and says, "Why do you not say this to the students?" and we just ... what? We have said it seven million times!' We think, if the council discussions will have the potential to be fruitful, the discussions must be contextualised and reach a deeper level.

In relation to our discussion about too much content in the course, one TE was afraid of being rude when talking about a colleague:

I can agree on the amount of content and that we push in too much stuff in a course, it is about the design of the teacher education. We take on a lot of responsibility as teacher educators and I sometimes think that ... I do not know how to express myself because I do not want be rude. However, I think my colleagues absolutely want to do the very best they can, and they make amazingly great work under the conditions, but I sometimes think that we are coaching and protecting our students too much.

As the TEs expressed more shortcomings than skills in relation to colleagues, we asked them to tell their visions of a collegial dream team; a discussion that often ended up in a vision of how to work. As one TE said:

I would like to work with senior lecturers and professors who know a little bit more and represent a different perspective. To teach together and add their knowledge and skills. To get involved and in that way motivate the students. A commitment from everyone involved.

Another quote we want to highlight includes ideas about more collaboration:

We do not have that many possibilities for professional development. No, not much time for developing one's competence. To take part in colleagues' classes, and vice versa, a collegial exchange, that could be something.

This part of the web relates to the structural aspects of the ecological system and the social support from colleagues. When we interpret what seems to be of crucial importance, it is not about commitment to colleagues as much as another field in the web that deals with structure and content. 


\section{Structure and content: commitments impossible?}

The TEs talked about how structures tend to include issues related to too much content and how it is almost impossible to find time, for example, to make any changes when there is a change of the syllabi (RQ2).

When talking about the amount of content, one TE says:

I have to teach a little about a lot, in a very comprehensive way. I feel that maybe I can present more of an introduction and hope for progression later on. I have great faith in our education programme, but I sometimes feel unsure of my own efforts because the programme contains so much content, there is an enormous amount of content within the framework of the general courses. It is hard to see what the topic is and what general educational content is. It feels like we have a complete preschool teacher programme in just one semester.

One TE talked about a mismatch between content and form, leading the TEs to divide the course content into small pieces:

One just has to pass on, topic by topic, to get through. Never mind what you did yesterday. It is like 'today it's a new day and now it's a new exam paper'. I think we need to be more coherent about what we say about content and form, because now it feels like disharmonious.

Afterwards, we talked with this TE about how some students perceived lack of time to process the content, thereby contributing to surface learning. There was an agreement among most of the TEs that students actually have enough time to process and solve their tasks. Nevertheless, not all educators seem to be aware ofor have not thought of - the students' need of support to make proper use of the time.

Another solution to the problem with too much content is to create a context where the content is thematised to enable students to see a common thread but the TEs worry that when they do that it may be more obvious to them than to the students.

Several of the TEs talked about their visions to enable students to reach a deeper level of knowledge. However, it is not simple or unambiguous. One TE raised the issue of what students really need:

It is unreasonable to go in depth with all the subjects and all the problems. I experience it as if the students are partly unprepared to reach a deeper level, due to their habits just scratching the surface. They have finished many 
courses at a basic level but may not have experience with deepening their knowledge. Moreover, the question is: what do they need? I am not sure I know. Do they need very different knowledge or do they need deeper specialization in specific areas. It is an ideological issue.

This part of the web foremost relates to the material aspect of the ecological system holding aspects of TEs working conditions. Issues of content and structure relate to wishes of more and clearer guidance, from the faculty board and the related office.

\section{Internal and external commitments: steering and control}

A common view among the TEs show that they wanted more support from the faculty board office (RQ1, RQ2). There are examples of dialogues, which were perceived positively, such as when the TEs are to consider various proposals about changes from the faculty board. There are also examples of the opposite when dialogues are perceived more or less as quarrels or negotiations. One TE says:

We have always had to quarrel with the office about e.g. practicum periods, like 'do not do it like that - do it like this instead' to make it work. I have really missed a clear management in many aspects on how to think about the preschool teacher education programme. There is a great deal of unfamiliarity about the programme, and those who decide seem to know more about which verbs should be included in the syllabus rather than what we teach about.

A subject TE talks about the lacking subject knowledge among those who formulate the syllabi and how the design of the new syllabus is problematic when the TEs plan their teaching. It is hard to know who to contact and who to get answers from when complaining.

On the one hand, there is a feeling of strong control from the office on demands to report syllabi goals and examination tasks. On the other hand, the TEs talked about freedom to organise the courses themselves. However, this was a less appreciated freedom, and rather seen as disinterest from the faculty board and the office. One TE says: 'Nobody checks what I am doing. To get feedback from more than the students would be exciting. For example, to discuss how you are as a teacher.'

When it comes to external steering and control, several TEs referred to the ongoing evaluation from UKÄ as an opening for a new approach, showing that the local steering and control might have been too hard. One TE says: 
There is a lot of content that is included because of tradition. Now I realise we probably have more space to be able to decide for ourselves than the faculty board understands. I can see that we do not need to do as we have always done.

Some parts have been more obvious during the evaluation, such as scrutinising the syllabi. One educator says with a glint in the eye:

It has become relevant to read syllabi, to read learning objectives and keep on talking and talking with the office for hours. Then you are a bit "brainwashed" and start to think like constructive alignment and assessment criteria are almost sexy.

This part of the web relates to structural aspects of the ecological system including TEs wishes of support from the faculty board. No matter what commitments the TEs express, there are norms, values, and not the least, strong traditions that continue to influence content and form of the preschool teacher education programme.

Norms, values and traditions: strong threads in the fabric of webs

Some TEs referred to 'the old days' and how the good traditions seem to have been lost in favour of new values holding measurability and accountability (RQ2). For example, the need for many tasks to reach one single syllabi goal. When talking about why it has become a perceived burden one TE says:

We may have such a tradition. I reflected on this as a newcomer; that the students' time was very scheduled, for better or for worse. I do not know, I think it is traditions. It is how it should be.

Others try to break with traditions and norms such as 'it has always been like this' instead of doing the same things as their colleagues. One TE says: 'Ever since I got the responsibility myself, I have tried to break with the image that certain parts are difficult and miserable.'

Yet, another example shows difficulties among the TEs to appreciate what breaks the norms. One TE talked about a student who performed very well in a task. However, the student did not follow the expected way to structure and write the task, causing discussions as to whether the student should pass or fail. After rather hard discussions with colleagues, the student passed and received a good grade.

This part of the web relates to cultural aspects of the ecological system, including collective notions about good preschool teacher education. Our 
interpretation is that these webs of commitments might be obstacles or difficult circumstances when shaping a student-centred preschool teacher education. However, we also argue that TEs are aware of the relationships between themselves and the commitments in all fields of the web and make use of it as possibilities. The following section shows some examples of what we consider aspects of these TEs' visions to shape a student-centred teacher education programme.

\section{Aspects of student-centred education}

Awareness of the importance of one's own role as a TE had not always been clear. One of the interviewees says:

We have not taken a major student perspective before. I am very surprised of the difference it makes when we take the students into the planning. We must consider what kind of students we have today; what kind of students we are teaching.

The same TE continues by stressing how colleagues share the same goals, helping the students' progression (RQ3):

We are developing tools which enable them to work in teams. It is important to have such tools quite early in their studies. We talk to each other in the teacher council, e.g. which concepts to use etc. Students need help with study techniques.

Interviewees provided several examples of how assignments are adapted to meet the needs of students here and now. The TEs have a great trust in students' efforts, trying the very best to challenge them to make them more active. For example, TEs use to plan a couple of days free from classes before exams to meet the problem with too much content. TEs want students to ask questions, simultaneously being aware that it is hard for students to ask about things they have no experience of. We also heard of how the TEs strived to let the students meet their need of knowledge as future preschool teachers. When TEs reflected on their work, the dual mission of educating for both the present and the future professional role became visible. They see their task as follows: to connect what is somewhat difficult theoretically; making the theories meaningful in the teaching they experience with the children; and to challenge the students into developing new ways of thinking. One TE says: 'I want them to understand why they need theoretical knowledge when they meet with children and guardians.'

Even though some of the examples above even contradict the TEs commitment in other parts of the web, we believe that the necessity to deal with all 
commitments had helped the TEs to reach an awareness of how to proceed towards a student-centred education. These examples also show how the TEs take advantage of experiences from the past as well as the present situations when developing their thoughts into actions on how to better support students. The TEs make use of their agency in order to shape a better preschool teacher education, and not the least to shape a better preschool in the Swedish society, through well-educated preschool teachers in what we might consider efforts of an education as and for public good.

\section{Concluding discussion}

In this paper, we have shown how the internal demands in the form of students (RQ3) constitute the main part of the TEs webs of commitments. What seem to worry the TEs are changes in the groups of students attending the current teacher education programme. The TEs are not prepared to handle these changes but do so in the best way they can. Our results show how the TEs ask for support from different actors. Beside the supportive but sometimes obstructive colleagues, TEs ask for more support from the local faculty board and its office (RQ1). We interpret their wishes as the controlling factor which overshadows the supporting one. Nevertheless, the TEs strive to overcome these obstacles and the lack of support does not prevent them from expressing visions of a future preschool teacher education.

Our related theoretical ground on teacher agency was helpful in our analyses to get insight on what experiences the TEs relate to when expressing their visions in the shaping of the preschool teacher education. Even though we have shown how external demands (RQ2) from a national evaluation has brought new insights and new concepts into the TEs work, we might ask what kind of teacher agency is performed in the HEIs in general. To what extend is the TEs' agency allowed to be achieved or hindered, and in what ways are external and internal demands affecting TEs agency? Structures tend to include issues related to too much content and impossibilities to find time to make any syllabi changes. Such limitations will for sure affect both the TE profession, the students' future teacher profession as well as developing teacher agency. Even if the good traditions seem to have been lost in favour of new values, including measurability and accountability, we have shown that the TEs make use of their agency to overcome strong and less desirable traditions. We have also shown how they make use of their agency when shaping the education in a student-centred way, making us stress that the collective notions of good preschool teacher education seem to include strong threads in the fabrics of webs. However, dealing with the theoretical concept of teacher agency we suggest more research to get insight on different kinds of and 
different amounts of agency related to the structural aspects in teachers/teacher educators every-day working environments. Our combined results from this study show how TEs are part of webs of commitments that we regard as related fields and threads dependent on each other rather than separate parts. It also means teacher educators' agency is dependent on all the fields in the webs. A conclusion from such reasoning means the preschool teacher education programme is fragile and if any threads in the web breaks, the whole programme will be damaged.

The limitations of our study include the small number of interviewed TEs and the fact that they all work at the same HEI. We cannot know if the same results would have appeared with a broader sample of TEs and the results and conclusions must be interpreted with respect to these limitations.

Finally, we will discuss some of our results in relation to the different actors in the preschool teacher education programme and provide suggestions on what kind of future research is needed to deepen our understanding on the complexity of preschool teacher education.

One of the most interesting findings was the discrepancy between the TEs and their students' expectations regarding how much time is spent on studies, for example. We need to bring students and TEs perspectives together and make clearer what ideas need to change. There is a lot of research on the importance of constructive relationships between TEs and students (Toom et al., 2017) and that these relationships are crucial for a good learning environment (Trigwell et al., 1999), but these ideas are not emphasized by the TEs in our study. One exception is their concern about some colleagues sometimes being a bit too "coachingoriented". In research on teacher education, an often-repeated worry includes concerns about beginner teachers who are not ready to meet preschool/school practice. This phenomenon has been discussed as the 'practical shock' or the gap between theory and practice that students have not been sufficiently prepared for. Our results show the readiness among the TEs to change their teaching to fit the new group of students. However, the TEs also shared their visions to do more and do things differently. On the other hand, they also expressed the feeling of being captured in structures, goal fulfilments as well as lack of time, resulting in changes to be postponed to a better future. It was also surprising that no TEs related their commitments to the students' practicum places, as we know that practicum places play an important role in teacher education (Zeichner, 2010). Lack of such discussions might be a bias related to our design making us involved in a jointly constructed knowledge. However, it indicates the need for additional research focusing partly on TEs' awareness of their own role related to students learning, partly focusing the connection between the scientific parts of the education programme and the proven experiences that are supposed to form the students' practicum skills. 
The TEs are striving to present an education built on the idea about constructive alignment. However, a similar approach seems to be missed in relation to the way the faculty board and its office relates to the TEs. Some TEs reported not having any support at all, while others talked about how they have to quarrel and negotiate about obvious things. Yet, others seem to have given up their professional identity, and capitulated to the performative and standard-based system, described by Ball (2006). It became obvious when one TE described how talking and talking about assessments and constructive alignments repeatedly appeared as sexy concepts. Overall, when reasoning about commitments to the faculty board and its staff, the TEs reported that they would appreciate more support and engagement to be able to support everyone's aims to offer good preschool teacher education. To realise the TEs visions and dreams, we argue the need of all actors within the HEI to make visible and discuss their demands and webs of commitments with each other, not the least the leaders.

Some of the TEs talked about their teaching in a way that, without explicitly using the concept, relates to SCLT (Fitch, 2017), which invites the students to take an active role in their education. When talking to the TEs on their visions and dreams, our overall feelings were that the TEs were eager to create a good preschool teacher education, not only for the current students but also to contribute to a good future preschool in which these students can act as professional teachers. They share the same visions as the TEs in Goodwin et al. (2014), when relating to the children those students will teach in their future preschools.

We are attracted to the idea from Sugrue and Solbrekke (2020) about overcoming traditional orientations, characteristics and underpinning values by acting in a complex web of commitments and a deliberative way of leadership. We think that such underpinning ideas are valuable not only for leaders but for teacher educators to engage students in interactive dialogues on the meaning of becoming a preschool teacher and continue contribute to public good. It is indeed a challenge, and, in order to fulfil the TEs visions, we see a need for discussions led by the faculty board on what the concept of student-centred education actually means and how the support to reach it might be developed.

Finally, we argue that there is a need to make students aware of possible problems and provide tools, for example, to make use of deliberation and dialogue (Englund \& Bergh, 2020), to think and act as future teachers as a way of preparing preschool teacher education as and for public good. 


\section{Author biographies}

Senior lecturer Katarina Ribaeus focuses her research primarily on issues of democracy and values education from various aspects. Preschool's democratic mission as well as student teachers' development of readiness for action are projects that are among her area of research interests. Katarina has also been active in the preschool teacher program as a programme leader, course leader and teacher as well as in the education of local teacher educators. ORCID: https://orcid.org/0000$\underline{0002-7905-0822}$

Professor Annica Löfdahl Hultman's area of research interest is within the field of education policy, teacher profession in general and specifically in Early Childhood. She is currently engaged in studies of policy changes in Early Childhood Education as well as in studies of teachers' net-based rebellion groups in which teachers' posts contribute to form their profession. ORCID: https://orcid.org/00000001-8510-5546 


\section{References}

Ball, S. J. (2006). Performativities and fabrications in the education economy: Towards the performative society. In H. Lauder, P. Brown, J.-A. Dillabough \& A. H. Halsey (Eds.), Education, Globalization \& Social Change (pp. 692701). Oxford: Oxford University Press.

Biesta, G., Priestly, M., \& Robinson, S. (2015). The role of beliefs in teacher agency. Teachers and Teaching, 21(6), 624-640.

https://doi.org/10.1080/13540602.2015.1044325

Brinkmann, S., \& Kvale, S. (2014). InterViews: Learning the craft of qualitative research interviewing. Los Angeles, CA: Sage Publications.

Bryman, A. (2011). Samhällsvetenskapliga metoder [Social Research Methods]. Stockholm: Liber

Edling, S., \& Liljestrand, J. (2020). Let's talk about teacher education! Analysing the media debates in 2016-2017 on teacher education using Sweden as a case. AsiaPacific Journal of Teacher Education, 48(3), 251-266. https://doi.org/10.1080/1359866X.2019.1631255

Englund, T., \& Bergh, A. (2020). Higher education as and for public good. Past, present and possible futures. In D. T. Solbrekke \& C. Sugrue (Eds.), Leading higher education as and for public good. Rekindling Education as praxis (pp. 37-52). London: Routledge

Fitch, B. (2017). Standardized to student-centered: A systemic approach to navigating the transition, finding balance and creating equitable 21st century learning environments. San Jose State University, Dissertations.

6. https://doi.org/10.31979/etd.rdvu-3jcx

Green, C., \& Harrington, C. (2020). Student-centered learning: In principle and in practice. Lansing, MI: Michigan Virtual University.

Greener, S. (2015). What do we mean by "student-centred" learning? Interactive Learning Environments. 23(1), 1-2. https://doi.org/10.1080/10494820.2015.1005423

Goodwin, A. L., Smith, L., Souto-Manning, M., Cheruvu, R., Reed, R., Tan, M., \& Traveras, L. (2014). What should teacher educators know and be able to do? Perspectives from practicing teacher educators. Journal of Teacher Education, 65(4), 284-302. https://doi.org/10.1177/0022487114535266

Hoidn, S., \& Klemenčič, M. (2021). The Routledge international handbook of student-centered learning and teaching in higher education. New York: Routledge.

McKenna, S., \& Quinn, L. (2021). Misconceptions and misapplications of studentcentered approaches. In S. Hoidn and M. Klemenčič (Eds.) The Routledge 
international handbook of student-centered learning and teaching in higher education. (pp. 109-210). New York: Routledge.

Lilja, P. (2010). Globalisering, utbildningsreformer och nya förutsättningar för läraryrket. In J. Qvarsebo \& I. Tallberg Broman (Eds.), Från storslagna visioner till professionell bedömning: om barndom, utbildning och styrning [From great visions to professional assessment: On childhood, education and steering]. (pp. 206-220). Malmö Högskola, Lärarutbildningen.

Löfdahl Hultman, A., \& Ribaeus, K. (2021). "Det verkar som om de vill att vi ska hoppa av" Förskollärarstudenters lärartillblivelse $i$ en performativ lärarutbildning [It seems like they want us to drop out. Preschool student teachers becoming in a performative teacher education]. Konferensvolym från fjärde konferensen i pedagogiskt arbete. Tilde, (pp. 23-36). Umeå universitet.

Murray, J. (2012). Performativity cultures and their effects on teacher educators' work. Research in Teacher Education, 2(2), 19-23.

OECD. (2005). Teachers matter: Attracting, developing and retaining effective teachers. Paris: Organisation for Economic Co-operation and Development. https://www.oecd.org/education/school/34990905.pdf

OECD. (2009). Evaluating and rewarding the quality of teachers: International practices, OECD Publishing, Paris.

https://doi.org/10.1787/9789264034358-en

Oolbekkink-Marchand, H.W., Hadar L.L., Smith, K., Helleve, I., \& Ulvik, M. (2017). Teachers' perceived professional space and their agency. Teaching and Teacher Education, 62, 37-46.

https://doi.org/10.1016/j.tate.2016.11.005

Priestly, M., Biesta, G., \& Robinson, S. (2015). Teacher Agency: An ecological Approach. London: Bloomsbury Academic.

Ribaeus, K., Enochsson, A. \& Löfdahl Hultman, A. (2020). Student teachers' professional development: early practice and horizontal networks as ways to bridge the theory-practice gap. Journal of early childhood teacher education. Online version.

https://doi.org/10.1080/10901027.2020.1797956

Sjöberg, L. (2019). Organising the 'industrialisation of instruction': Pedagogical discourses in the Swedish Primary Teacher Education programme. Journal of Praxis in Higher Education, 1(1), 37-59. https://doi.org/10.47989/kpdc.vol2.2.2020

Solbrekke, T. D., \& Englund, T. (2011) "Bringing Professional Responsibility Back In.” Studies in Higher Education, 36 (7), 847-861. https://doi.org/10.1080/03075079.2010.482205 
Solbrekke D. T., \& Sugrue, C. (Eds.) (2020). Leading higher education as and for public good. Rekindling Education as praxis. London: Routledge.

Solbrekke, D.T., Sugrue, C., \& Sutphen, M. (2020). Leading in a web of commitments: Negotiationg legitimate compromises. In D.T. Solbrekke \& C. Sugrue (Eds.) Leading higher education as and for public good. Rekindling Education as praxis. (pp. 53-69). London: Routledge.

Sugrue, C., and Solbrekke, D.T. (2020). Leading higher education. Putting education center stage. In D.T. Solbrekke \& C. Sugrue (Eds.) Leading higher education as and for public good. Rekindling Education as praxis.(pp. 18-36). London: Routledge.

Souto-Manning, M. (2019). Transforming university-based teacher education: Preparing asset-, equity-, and justice-oriented teachers within the contemporary political context. Teachers College Record, 121(6), 1-26.

Trigwell, K., Prosser, M., \& Waterhouse, F. (1999). Relations between teachers' approaches to teaching and students' approaches to learning. Higher Education, 37(1), 57-70. https://doi.org/10.1023/A:1003548313194

Toom, A., Pietarinen, J., Soini, T., \& Pyhältö, K. (2017). How does the learning environment in teacher education cultivate first year student teachers' sense of professional agency in the professional community? Teaching and Teacher Education, 63, 126-136. https://doi.org/10.1016/j.tate.2016.12.013

Zeichner, K. (2010). Rethinking the connections between campus courses and field experiences in college- and university-based teacher education. Journal of Teacher Education, 61(1-2), 89-99. https://doi.org/10.1177/0022487109347671 